\title{
Host-parasite transcriptomics during immunostimulant-enhanced rejection of salmon lice (Lepeophtheirus salmonis) by Atlantic salmon (Salmo salar)
}

\author{
Ben J.G. Sutherland ${ }^{a \dagger}$, Jennifer M. Covello ${ }^{b}$, Sarah E. Friend ${ }^{c}$, Jordan D. Poley ${ }^{b}, K_{i m}$ W. Koczka ${ }^{a}$, \\ Sara L. Purcell ${ }^{b}$, Tara L. MacLeod ${ }^{b}$, Bridget R. Donovan ${ }^{b}$, Jorge Pino ${ }^{d}$, Jose Luis González-Vecino ${ }^{e}$, \\ Javier Gonzalez $^{d}$, Jose Troncoso ${ }^{d}$, Ben F. Koop ${ }^{a}$, Simon L. Wadsworth ${ }^{d}$, and Mark D. Fast ${ }^{\text {bc* }}$ \\ ${ }^{a}$ Centre for Biomedical Research, Department of Biology, University of Victoria, Victoria, BC V8W 3N5, \\ Canada; ${ }^{b}$ Hoplite Lab, Department of Pathology and Microbiology, Atlantic Veterinary College, \\ University of Prince Edward Island, Charlottetown, PE C1A 4P3, Canada; ${ }^{\mathrm{c} S}$ chool of Marine and

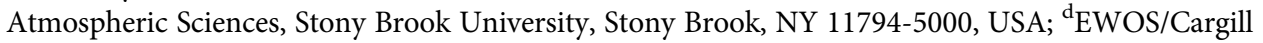 \\ Innovation Center-Colaco, Colaco KM5, Puerto Montt, Chile; ${ }^{\mathrm{e}} \mathrm{EWOS} /$ Cargill Innovation \\ Center-Dirdal, 4327 Sandnes, Norway \\ *mfast@upei.ca \\ ${ }^{\dagger}$ Current address: Institut de Biologie Intégrative et des Systèms (IBIS), Département de biologie, Université \\ Laval, Québec, QC G1V 0A6, Canada
}

\section{OPEN ACCESS}

\section{Citation: Sutherland BJG, Covello JM, Friend SE, Poley JD, Koczka KW, Purcell SL, MacLeod TL, Donovan BR, Pino J, González- Vecino JL, Gonzalez J, Troncoso J, Koop BF, Wadsworth SL, and Fast MD. 2017. Host-parasite transcriptomics during immunostimulant-enhanced rejection of salmon lice (Lepeophtheirus salmonis) by Atlantic salmon (Salmo salar). FACETS 2: 477-495. doi:10.1 139/ facets-2017-0020 \\ Editor: Vance L. Trudeau}

Received: February 26, 2017

Accepted: May 9, 2017

Published: June 8, 2017

Copyright: ( 2017 Sutherland et al. This work is licensed under a Creative Commons Attribution 4.0 International License (CC BY 4.0), which permits unrestricted use, distribution, and reproduction in any medium, provided the original author(s) and source are credited.

Published by: Canadian Science Publishing

\section{Abstract}

Salmon lice (Lepeophtheirus salmonis) are important ectoparasites of wild and farmed salmonids and cause major losses to the salmon farming industry throughout the Northern Hemisphere. With the emergence of resistance to several commonly used parasiticides, novel control strategies and integration of multiple treatment options are needed, including host immunostimulation. Here, we investigate the effects of a functional feed containing a peptidoglycan and nucleotide formulation on L. salmonis infection of Atlantic salmon (Salmo salar) by characterizing lice infection levels, the expression of several host immune genes, and the parasite transcriptomic response to the immunostimulated host. Although initial infection intensities were low, the low dose (LD) immunostimulant diet reduced the total lice burden by $50 \%$ relative to controls. Immunostimulant fed hosts upregulated interleukin-1 $\beta$ in the skin and spleen. This gene has been implicated in successful responses of several salmonid species to salmon lice but is typically not observed in Atlantic salmon, suggesting a favorable influence on the immune response. Lice infecting LD immunostimulated salmon overexpressed genes putatively involved in parasite immunity, including carboxylesterases, and underexpressed genes putatively involved in feeding (e.g., proteases). These lice response genes further improve the characterization of the transcriptome of the non-model parasite by identifying genes potentially involved in evading host immunity.

Key words: functional feeds, host-parasite interaction, immunostimulation, salmon aquaculture, sea lice, transcriptomics

\section{Introduction}

Ectoparasitic arthropods have challenged terrestrial agricultural production for decades and pose serious human health risks as vectors of disease. In aquatic habitats they are significant pests to wild 
and farmed fishes worldwide. Parasitic copepods, and in particular those from the Family Caligidae (known as sea lice) such as Lepeophtheirus salmonis, cost the aquaculture industry hundreds of millions of dollars annually due to treatment costs and reduced growth or value of fish (Costello 2009). There are additional consequences of infection treatments, such as increased chemical inputs into the environment (Burridge et al. 2010; Veldhoen et al. 2012). Recent reviews highlight the impact of lice on salmon (Fast 2014), the emergence of drug resistance in sea lice (Aaen et al. 2015; McNair 2015), and sea lice biology and control strategies in aquaculture (Torrissen et al. 2013).

Variation in host response to sea lice infection is common inter- and intra-specifically. Among species, strong inflammatory and cellular immune responses are associated with reduced infection intensities in coho salmon (Oncorhynchus kisutch) and pink salmon (Oncorhynchus gorbuscha) (Johnson and Albright 1992; Jones et al. 2007; Braden et al. 2012, 2015; Sutherland et al. 2014). Within species, heritable differences in susceptibility indicate potential for selective breeding (Kolstad et al. 2005; Gjerde et al. 2011). Outcomes of infection differ depending on these and other factors, such as host life stage (Jones et al. 2008b; Sutherland et al. 2011). Infection outcomes can include growth reduction, behavioral changes, osmotic imbalance, stress response, and others, even mortality (Pike and Wadsworth 1999; Wagner et al. 2008; Fast 2014). Improved understanding of the mechanisms and pathways underlying host resistance is important for effective breeding (Yáñez et al. 2014), for predicting effects of infection in wild populations, and for tailoring immunostimulant diets against specific infections (Alvarez-Pellitero 2008). The use of targeted functional feeds has become increasingly important in aquaculture, including in-feed immunostimulants (Jensen et al. 2015). Approaches using in-feed immunostimulation are favoured as these can be administered without handling stress and are easily integrated into management practices, are active against multiple life stages, and are not likely to result in resistance development (Burka et al. 1997). This process typically involves presenting the fish with a pathogen-associated molecular pattern (PAMP) and stimulating an innate immune response; for example, using peptidoglycan to stimulate antimicrobial peptide gene expression in rainbow trout (Oncorhynchus mykiss) (Casadei et al. 2013).

Alternative treatment options are especially needed due to recent development of multiple chemical drug resistance in sea lice (Aaen et al. 2015; McNair 2015). Some of these alternate approaches include biological control (cleaner fish), mechanical delousing (including sieves and tank filters), regulation improvements, and selective breeding (for review see Torrissen et al. 2013; Gharbi et al. 2015). Immunostimulation is another option for treatment, temporarily increasing the natural immunity of the host or directing it towards a more appropriate response type (Bricknell and Dalmo 2005). Pulse doses of immunostimulation are used to avoid tolerance to the immunostimulant and can be used in periods of increased disease risk (Bricknell and Dalmo 2005). Complementary approaches may be effective when applied in a treatment rotation strategy and may reduce the burden on chemical parasiticides.

Several immunostimulation approaches for salmon lice have been developed, which have used the current knowledge of appropriate salmon defenses against lice (e.g., innate mucosal responses). Covello et al. (2012) tested the effectiveness of incorporating CpG oligodeoxynucleotide (ODN) or yeast extracts into post-smolt Atlantic salmon (Salmo salar) feed. Salmon on the treated diet had reduced $L$. salmonis infection levels ( $\sim 40 \%$ lower than controls) and showed enhanced site-specific inflammation. The difference in infection levels between control and treated fish increased over time, suggesting that the response to the feed was maintained (Covello et al. 2012). Purcell et al. (2013) identified that a previous exposure to lice resulted in lower reinfection density than naïvely infected salmon, and that this effect was increased further through CpG-ODN immunostimulation. Salmon with the lowest levels of lice (i.e., previously exposed and immunostimulated) had the highest expression of il-1 $\beta$ (Purcell et al. 2013). Enhanced defenses by CpG-ODN are dose dependent; at lower 
doses, the feed still increased interleukin-1 $(i l-1 \beta)$ expression in the head kidney but did not provide as much protection as evidenced by infection levels being $\sim 18 \%$ lower than controls (Poley et al. 2013). Dose-dependent host immunostimulation can augment innate immunity and local inflammation to reduce lice burdens. Other approaches have been taken to immunostimulate against salmon lice infections, although mechanisms of rejection remain unknown (see Jensen et al. 2015).

Here, we evaluate the effects of a commercial immunostimulant diet formulation composed of bacterial cell wall extract peptidoglycan on lice rejection and on parasite transcriptome profiles using a L. salmonis oligonucleotide microarray (Sutherland et al. 2012; Yasuike et al. 2012). We also evaluate the expression of several immune-related genes in the immunostimulated host using reverse transcription quantitative PCR (RT-qPCR). Characterizing the dynamics of the infection alongside molecular responses of both the parasite and the host informs on the efficacy and potential of dose-dependent immunostimulation of the hosts, as well as the effect of the stimulated host on L. salmonis molecular physiology.

\section{Materials and methods}

\section{Animals}

Atlantic salmon smolts were obtained from Buckman Creek Hatchery, Pennfield, New Brunswick, Canada. As per Canadian federal fish health regulations for transfer of fish, a disease-free certification from a fish health professional determined this source of fish and eggs pathogen-free (i.e., free of salmonid diseases of importance). These fish were transported to the Aquatic Animal Facility in the Atlantic Veterinary College at the University of Prince Edward Island (UPEI) (Charlottetown, Prince Edward Island, Canada). All experimental protocols for the use of fish followed the guidelines provided by the Canadian Council on Animal Care (2005; ccac.ca/Documents/Standards/Guidelines/ Fish.pdf) and were submitted for review and approval to the UPEI Animal Care Committee (UPEI Animal Care Protocol \#10-014).

Fish $(n=40-45 / \operatorname{tank})$ were held in 10 circular flow-through tanks containing $250 \mathrm{~L}$ of $11{ }^{\circ} \mathrm{C}$ freshwater for 3 wk to acclimate. The system was then switched to saltwater (Instant Ocean ${ }^{\circledR}$, Cincinnati, Ohio, USA) recirculation over $7 \mathrm{~d}$, resulting in a final salinity of $33 \mathrm{ppt}$. Fish were held in saltwater for a further 2 wk to acclimatize to the saltwater $\left(11.5^{\circ} \mathrm{C}, \mathrm{DO}>7.0 \mathrm{mg} / \mathrm{L}, \mathrm{pH} 7.9\right.$, ammonia/nitrite/ nitrate monitored). During this period, fish were fed a control diet at $1.5 \%$ body weight/day, divided over two feeds. Throughout the study, fish were kept on a light:dark cycle of $14 \mathrm{~h}: 10 \mathrm{~h}$. At the start of the study, fish weighed $98.2 \pm 5.2 \mathrm{~g}$ (mean \pm SEM), and at the end of the study, fish weighed $177.0 \pm 10.1 \mathrm{~g}($ mean \pm SEM $)$.

Egg strings from L. salmonis were harvested from sea cage cultured Atlantic salmon (New Brunswick, Canada) from the BMA2A region (this region contains lice with elevated emamectin benzoate (EMB) resistance; Igboeli et al. 2014) and were aerated in $13{ }^{\circ} \mathrm{C}$ saltwater collected from the sea cage site and maintained at the Atlantic Animal Facility, Atlantic Veterinary College at 33-36 salinity through 10\% daily water changes until nauplii hatched and molted to copepodids $(\sim 6-8 \mathrm{~d})$.

\section{Feed production}

All feeds were produced at the EWOS Innovation facilities in Dirdal, Norway. The three different feed treatments were control/base feed ( $14 \%$ fat, $43 \%$ protein, maximum $3 \%$ fiber), low dose (LD; $0.12 \%$ peptidoglycan extract from bacterial cell wall with nucleotide formulation milled in with the base feed), and high dose (HD; $0.20 \%$ peptidoglycan extract from bacterial cell wall with nucleotide formulation milled in with the base feed). 


\section{Lice exposures and sampling}

Fish were infected following the method of Covello et al. (2012). Following seawater acclimatization, treatment tanks (total $=9$ tanks) were randomly assigned to one of three treatment groups and placed on one of the following three diets: control/base feed, LD, or HD. A system control tank was maintained on the recirculation loop but was separated from the other tanks by a plastic barrier. In this tank, the fish were held at the same density as the other tanks (40-45/tank) and fed the control/base feed but were not exposed to lice.

The infection and sampling regime is shown in Fig. 1. The day prior to feed adjustment, two fish from each tank were sampled and used as a time control (T0) for reference ( $n=20$ fish). For all following sampling times, six fish were sampled per tank ( $n=18$ fish per diet group). Fish were maintained on treated feed for $17 \mathrm{~d}$ and then sampled (T1). Eight days after T1, fish in all experimental tanks were exposed to L. salmonis copepodids at 10-12 lice/fish (initial exposure). Five days after the initial exposure, fish were sampled (T2). A second lice exposure and a third lice exposure (also at 10-12 lice/fish) were conducted 14 and $28 \mathrm{~d}$, respectively, after the first exposure to mimic a more constant low-level exposure as expected in the field. Fish were sampled again at 40 and $47 \mathrm{~d}$ post initial infection (dpii; T3 and T4, respectively; Fig. 1).

At each sampling time, feed was withheld for $24 \mathrm{~h}$ prior to sampling, and fish were euthanized with an overdose of tricaine methanesulfonate (MS-222: $250 \mathrm{mg} / \mathrm{L}$; Syndel Laboratories Ltd., Nanaimo, British Columbia, Canada). Lice were rapidly enumerated and staged, then flash frozen in dry ice. Spleen, skin, and head kidney were excised from each salmon individual and frozen on dry ice. In an effort to standardize the sampling, skin samples were always taken posterior to the left pectoral fin above the lateral line (as in Covello et al. 2012). All tissues were stored at $-80{ }^{\circ} \mathrm{C}$ until required for gene expression analysis.

\section{RNA extraction}

Total RNA was extracted from salmon spleen, skin, and head kidney samples, and L. salmonis whole individuals using Tri Reagent (Life Technologies, Carlsbad, California, USA) according to the manufacturer's instructions. Approximately $50 \mathrm{mg}$ of still frozen tissue was added to $1.5 \mathrm{~mL}$ of Tri Reagent and mechanically macerated with a homogenizer (VWR, Mississauga, Ontario, Canada). Then RNA

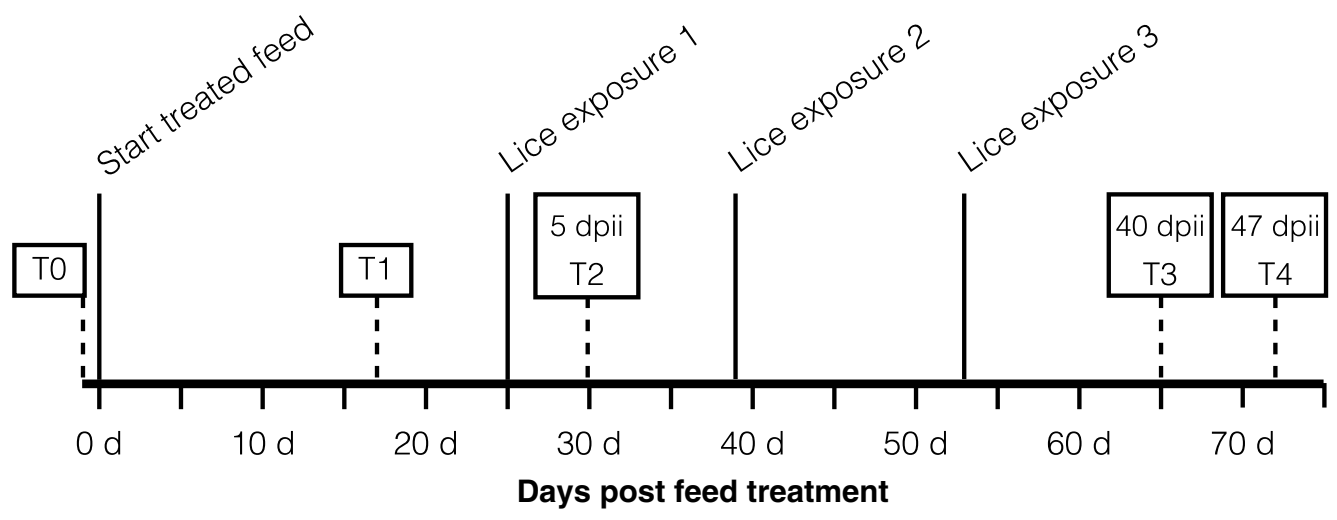

Fig. 1. Timeline of feed treatment and lice exposure. Fish were sampled prior to feed treatment (T0), $17 \mathrm{~d}$ post feed initiation (dpfi; T1), exposed to lice $25 \mathrm{dpfi}$ (lice exposure 1), sampled $5 \mathrm{~d}$ post initial infection (dpii; T2), exposed to lice again $39 \mathrm{dpfi}$ and again at $53 \mathrm{dpfi}$ (lice exposures 2 and 3). Two final samplings were conducted at $40 \mathrm{dpii}(65 \mathrm{dpfi}$; T3) and $47 \mathrm{dpii}(72 \mathrm{dpfi}$; T4), and at both T3 and T4, lice were also collected for transcriptome profiling. 
was extracted as per the manufacturer's instructions (Invitrogen, Carlsbad, California, USA). Resultant RNA was dissolved in 100-200 $\mu \mathrm{L}$ of molecular biology grade water and stored at $-80{ }^{\circ} \mathrm{C}$. Total RNA concentration was measured using the NanoDrop-2000 spectrophotometer (Thermo Scientific, Wilmington, Delaware, USA). A subsample of all salmon tissue RNA extractions (10\%) was tested for RNA quality using automated gel electrophoresis (Experion; Bio-Rad, Mississauga, Ontario, Canada), as per the manufacturer's instructions. The quality of salmon tissue RNA was good (RQI > 7.0) in over $90 \%$ of the samples tested. Five micrograms of the extracted RNA was then DNase treated using a TURBO DNase-free ${ }^{\mathrm{TM}}$ kit (Ambion, Foster City, California, USA) following the manufacturer's protocol. Lice samples were all tested using the Experion, and all used for the analysis were high quality (RQI > 7.0).

\section{Salmon RT-qPCR}

Synthesis of cDNA was performed on $1 \mu \mathrm{g}$ of DNase-treated total RNA using the Reverse Transcription System (Promega, Madison, Wisconsin, USA) and random hexamers, according to the manufacturer's instructions. Reverse transcriptase-free $(-\mathrm{RT})$ controls were included to ensure the absence of genomic DNA. cDNA samples were stored at $-20^{\circ} \mathrm{C}$ until use for qPCR.

Primer sets for the three reference genes (ef-1ab, rps20, and 18S) and four genes of interest (il-1 1 , il-8, toll-like receptor 9, and matrix metalloproteinase 9) were obtained from previous literature (Frost and Nilsen 2003; Sutherland et al. 2012; Supplementary Material 1). Each reaction was run in a 96-well plate (Eppendorf, Mississauga, Ontario, Canada) in $10 \mu \mathrm{L}$ reactions containing $0.5 \mu \mathrm{mol} / \mathrm{L}$ of each primer, $2 \times$ GoTaq $^{\circledR} \mathrm{qPCR}$ Master Mix (Promega), and $1 \mu \mathrm{L}$ of cDNA (diluted 1:1 in nuclease-free water). A no template control (NTC) was included for each primer pair and remained unamplified. Amplifications were carried out in an Eppendorf Mastercycler ep realplex ${ }^{2}$ under the following conditions: initial denaturation at $95^{\circ} \mathrm{C}$ for $10 \mathrm{~min}$, followed by 40 amplification cycles of $95^{\circ} \mathrm{C}$ for $15 \mathrm{~s}$, annealing for $15 \mathrm{~s}$ at $55^{\circ} \mathrm{C}$, and extension for $15 \mathrm{~s}$ at $72{ }^{\circ} \mathrm{C}$. Following this amplification, melt curve analysis was performed to ensure amplification of a single product.

The gene expression results were analyzed using qBasePLUS relative quantification framework software version 2.0 (Hellemans et al. 2007). Primer efficiencies were determined by analysis of 10-fold serial dilutions for the reference genes and 5 -fold serial dilutions for the genes of interest using pooled cDNA of experimental samples and samples from a separate experiment of cohort individuals $6 \mathrm{~h}$ after LPS injection. Efficiencies averaged $96 \%$ for all genes across salmon tissues, and all experimental samples were within the range of the standard curve. The stability of ef-1ab, rps20, and $18 s$ as reference genes was evaluated using geNORM (qBASE+ Biogazelle; Vandesompele et al. 2002), and the geometric mean of these reference genes was used to normalize target gene transcripts. Data were normalized per group by subtracting the pretreatment means from each treatment (i.e., $\mathrm{T}(0)$ expression level). $\log _{2}$-transformed data were used to test for significant differences between treatment groups over exposure time using linear models and pairwise Tukey's honest significant difference (HSD) tests in R ( $\mathrm{R}$ Core Team 2017).

\section{Salmon lice microarray analysis}

Total RNA was extracted from lice infecting control diet fish and LD diet fish from times T3 and T4 (Fig. 1). These individuals were used to hybridize to an L. salmonis $38 \mathrm{~K}$ oligonucleotide microarray (Sutherland et al. 2012). Samples consisted of pools of both male and female adult lice collected from the same fish (each sex in equal proportion within each sample; two to four individuals per pool). Seven pools were used from the control fish and four pools from the LD. As no clustering was viewed in initial data exploration by time point (T3 or T4) and due to low sample numbers, these two time points were merged for differential expression analysis. 
Samples were processed in a random order, using $200 \mathrm{ng}$ of total RNA as an input for reverse transcription and cDNA amplification to Cy5-cRNA using the Low Input Quick Amp Labeling kit as per the manufacturers' instructions (v6.5; Agilent Technologies, Santa Clara, California, USA). A reference pool was also synthesized as Cy3-cRNA using all possible treatment conditions (time points and treatments) and equal numbers of males and females in the reference. Aliquots of the reference pool were then stored at $-80^{\circ} \mathrm{C}$ until hybridization. Sample (Cy5) and reference pool (Cy3) combinations ( $825 \mathrm{ng}$ each) were hybridized to randomly ordered $4 \times 38 \mathrm{~K}$ microarrays as per manufacturer's instructions, with the optional Stabilization and Drying Solution ozone protection step (Agilent). After washing, slides were kept dark and at low ozone (ozone $\leq 8 \mathrm{ppb}$ ), and scanned on a ScanArray Express (Perkin Elmer, Waltham, Massachusetts, USA) at $5 \mu \mathrm{m}$ resolution. Photomultiplier tube settings were kept constant for the scanning and were optimized to obtain $\sim 1 \%$ saturated spots (Cy5:65; Сy3:60).

Microarray probe intensity values were quantified and flagged for quality in Imagene (v8.0; BioDiscovery, El Segundo, California, USA). These values were analyzed using limma (Smyth 2004; Ritchie et al. 2007) in R (R Core Team 2017). Probes were retained for analysis when at least three samples in any condition were $\geq 500$ for raw fluorescence in both channels. Probes saturated in all samples were removed from analysis. All spots were background corrected using the minimum function in limma (Ritchie et al. 2007). The arrays were normalized by within array loess normalization and between array quantile normalization using the Cy3 reference channel (Smyth and Speed 2003). Probes were tested for differential expression using linear models contrasting the LD and control treatments using eBayes fit (Smyth 2004). Differential expression required $p \leq 0.05$ and fold change $(\mathrm{FC}) \geq 1.5$.

\section{Salmon lice RT-qPCR validation}

The same RNA used for the microarrays was used for RT-qPCR. Total RNA $(1.9 \mu \mathrm{g})$ was reverse transcribed to cDNA using Superscript III (Invitrogen) as per the manufacturer's instructions for oligo dT priming. A representative sample from each condition was pooled, then diluted 7 -fold to be the first point on a 6-point, 5-fold dilution series used as a standard curve for primer testing. Quantitative PCR was performed on an MX3000P (Agilent) using SsoFast EvaGreen Supermix with low rox (Bio-Rad) as per manufacturer' instructions, and with the following thermal regime: $95^{\circ} \mathrm{C}$ for $30 \mathrm{~s}(1 \mathrm{cycle}) ; 95^{\circ} \mathrm{C}$ for $5 \mathrm{~s}, 55^{\circ} \mathrm{C}$ for $20 \mathrm{~s}\left(40\right.$ cycles); and $95^{\circ} \mathrm{C}$ for $5 \mathrm{~s}, 55^{\circ} \mathrm{C}$ for $10 \mathrm{~s}$ then increase by half-degree increments (dissociation curve). Primers had efficiency values between $80 \%$ and $110 \%$, and each pair amplified a single product in dissociation curve analyses. Amplicons were purified using SureClean (BioLine, Taunton, Massachusetts, USA) and sequenced as previously reported (Sutherland et al. 2011). Samples were diluted 20 -fold in water, and each was run in duplicate on a single plate. Replicates were within $0.5 \mathrm{Ct}$ for 193 of 195 sample-target combinations. Each gene/plate included a no RT control and an NTC. Negative controls did not amplify.

Data were exported from MxPro software (Agilent), imported into R, and analyzed using ReadqPCR and NormqPCR (Perkins et al. 2012; R Core Team 2017). Potential normalizers vcl, gstd2, flna, and rps20 were evaluated for stability using geNORM (Vandesompele et al. 2002) implemented within NormqPCR; the geometric mean of the two normalizers with the lowest $M$-value was used to normalize samples. Delta-delta $\mathrm{Ct}(\mathrm{ddCt})$ values were calculated by first subtracting the geometric mean of the normalizer genes ( $\mathrm{dCt}$ within NormqPCR) and then subtracting this value from the median $\mathrm{dCt}$ values for this gene. These ddCt values (i.e., $\log _{2}$ ) were used to correlate against the $\log _{2}$ microarray ratios to obtain the adjusted $R^{2}$ value from the linear model fit in R (R Core Team 2017). 


\section{Results}

\section{Salmon weights and lice infection intensity}

Weights were not different among groups prior to the start of experimental feeding (ANOVA $p=0.3 ; n=6$ per group). After the feed trial and lice infections commenced, the HD immunostimulated salmon were of lower weight, in general, than the control salmon (two-way ANOVA main effect treatment $p=0.02$ ), but the LD immunostimulated and control salmon were not different (Tukey's HSD $p>0.3$ ). The cause of this difference is not clear. Although the fish were increasing in size over the study, the differences between the groups remained approximately equal throughout the study (i.e., no treatment by time interaction). Missing values for more than half of the measurements at T4 due to a recording problem resulted in this time point being excluded from the weight comparison. All other time points had complete weight data.

Infection levels of salmon $5 \mathrm{dpii}$ (T2) were low in all groups (mean intensity $=0.81$ (CTL), $0.71(\mathrm{LD})$, and 0.90 (HD) lice per fish (lpf); Fig. 2) and all lice were in the chalimus I-II stage (Hamre et al. 2013). After the two additional lice exposures, numbers were increased in the CTL and HD salmon, but remained low in LD salmon at T3 and T4 (Tukey's HSD $p \leq 0.05$; Fig. 2), with on average 1.6 and $1.9 \mathrm{lpf}$ lower than controls ( $\sim 50 \%$ lower than controls).

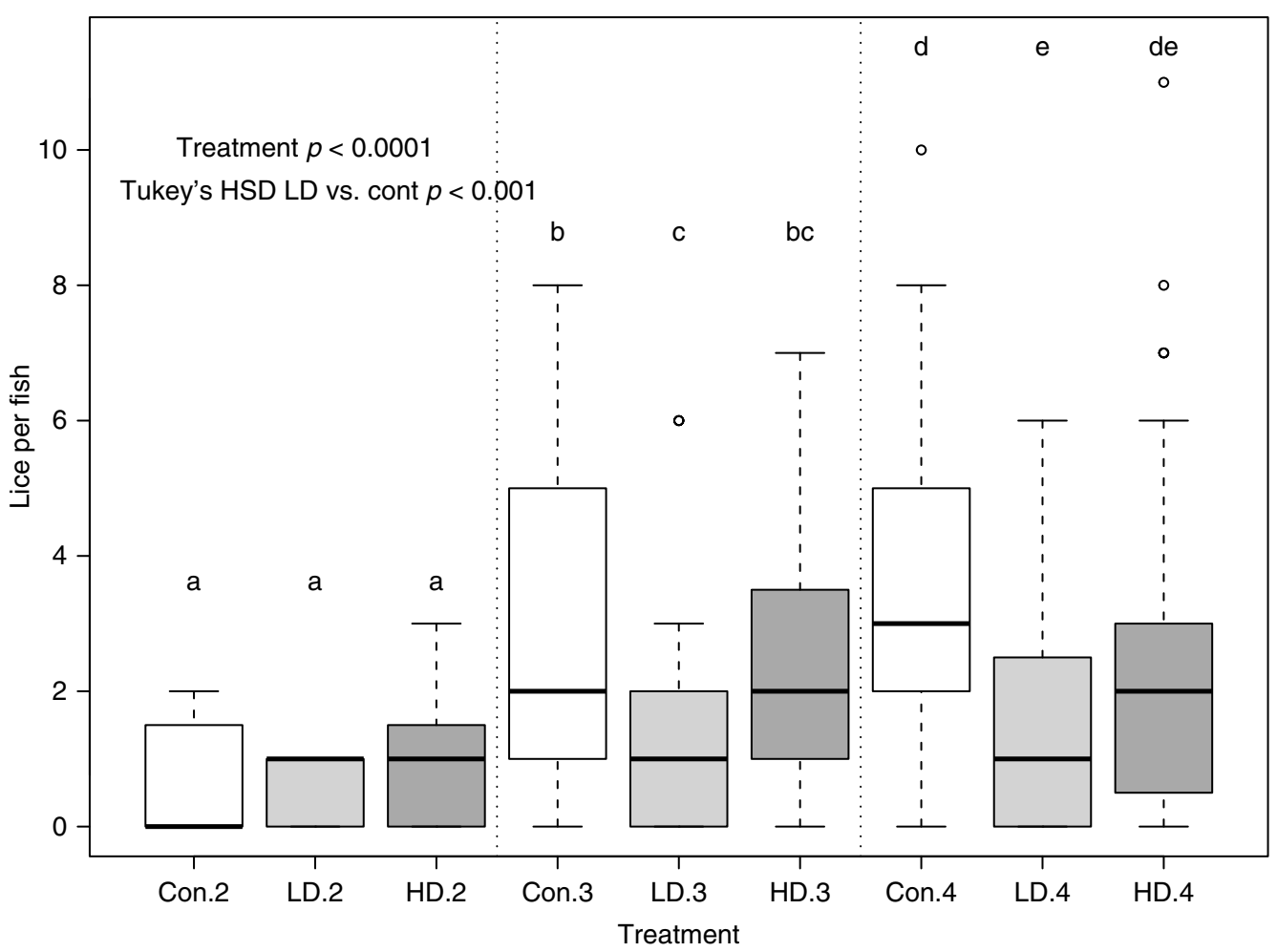

Fig. 2. Infection intensity among feed groups over time. Infection intensity (lice per fish) differed between the LD salmon and control at T3 and T4 (see Fig. 1 for timeline). Infection intensity did not differ between the control and HD salmon. Infection levels were low in general, but the LD group had $\sim 50 \%$ reduction in the number of lice infecting each fish at T3 and T4. Significance is analyzed within each time point and significant differences are indicated where box plots within a time point do not share a lowercase letter. Note that two additional lice exposures were conducted between T2 and T3, which resulted in the increased lice numbers at T3 and T4 (see Fig. 1). HSD, honest significant difference; LD, low dose; Con, control; HD, high dose. 


\section{Salmon gene expression responses}

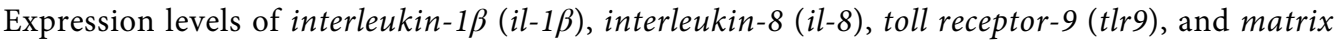
metalloproteinase-9 ( $m m p 9)$ were profiled in the skin, anterior kidney, and spleen prior to infection (17 d on feed; T1) as well as 5 dpii (T2), 40 dpii (T3), and 48 dpii (T4; see Fig. 1). Genes that differed among feed groups at the first profiled time (pre-infection) that remained different throughout the study reflect the effect of the feed. Genes that did not differ among feed groups but that changed over time may reflect the effect of the infection. Finally, genes that changed over time (effect of infection) and that were overexpressed in the feed group with the lowest levels of infection (effect of feed) may be involved in the protective response against the lice infection.

The strongest effect of the feed was for $i l-1 \beta$ in the skin, which was overexpressed in LD salmon consistently in all of the profiled times (main effect feed $p<0.005$; Fig. 3), with a significant difference identified between LD and control (Tukey's HSD $p=0.0056 ; 2.2$-fold overexpressed in LD), and LD and HD (Tukey's HSD $p<0.01$ ) but no interaction effect $(p=0.3$ ), nor pairwise significance between LD or HD and the control at any one specific time point (Tukey's HSD $p>0.05$ ). $i l-1 \beta$ was also slightly overexpressed in the spleen in both the LD and HD fish (main effect feed $p=0.04)$, but pairwise comparisons between LD and control were not significant $(p=0.1)$. The expression of this gene increased over time in all groups (main effect infection; $p=0.03$;
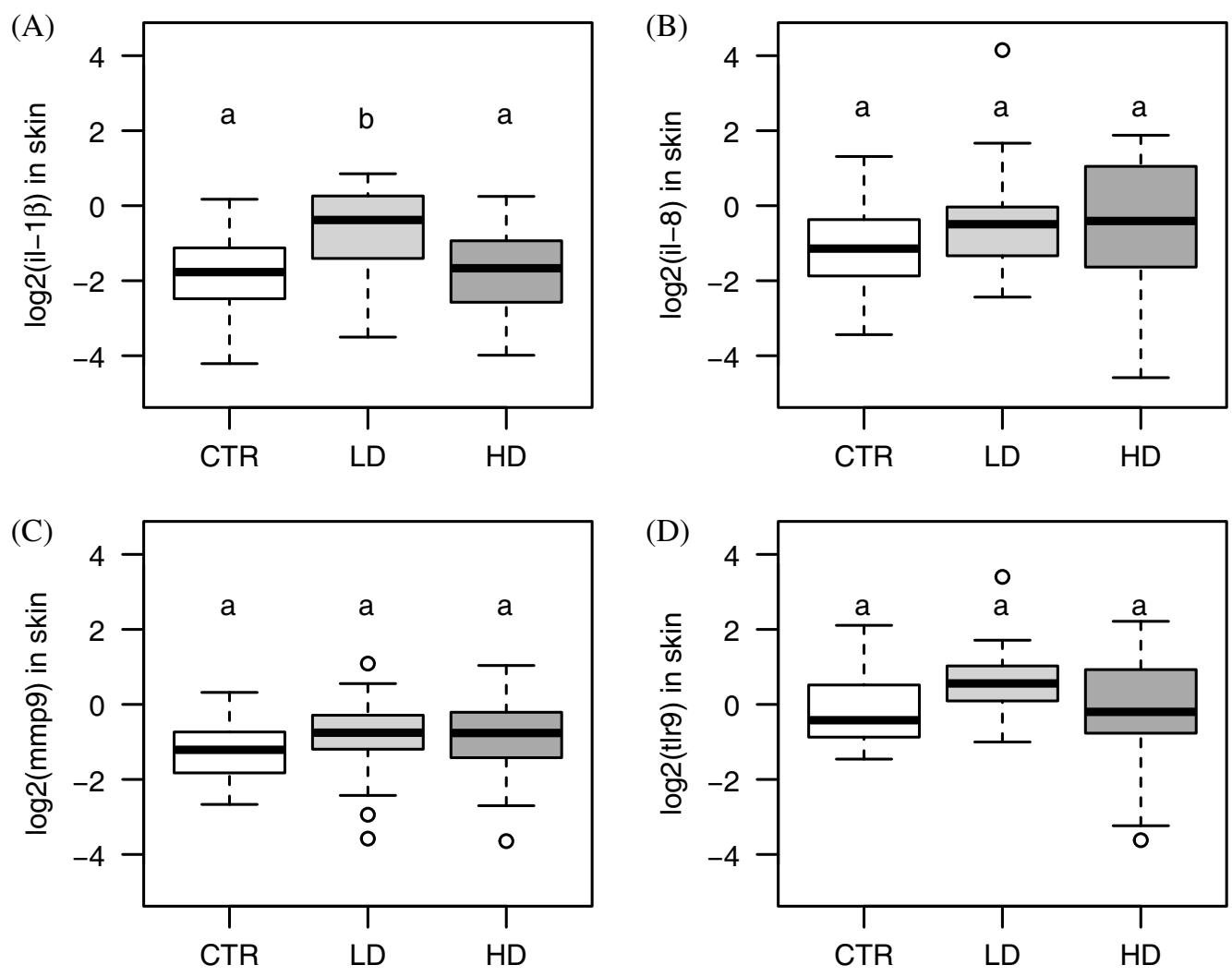

Fig. 3. Skin expression of (A) il-1 $\beta$, (B) il-8, (C) $m m p 9$, and (D) tlr9. The LD-immunostimulated salmon overexpressed $i l-1 \beta$ relative to either the control or HD-fed salmon. As there was no significant time by infection interaction, expression levels averaged over all days are shown. Gene expression levels for individual days, as well as for other tissues, are shown in Supplementary Material 2. CTR, control; LD, low dose; HD, high dose. 
Supplementary Material 2). Feed had no effect on $i l-1 \beta$ expression levels in the anterior kidney $(p>0.2)$, but a slight decrease over time was identified $(p<0.001)$.

Similar to $i l-1 \beta$, tlr 9 was overexpressed in the skin of the LD fish $(p<0.04$; Fig. 3), but the expression of $\operatorname{tr} 9$ in the skin reduced in all groups over time (Supplementary Material 2). il-8 expression decreased over time in all tissues and a trend towards overexpression in LD and HD was noted, although this was not significant ( $p=0.07$; Fig. 3; Supplementary Material 2). $m m p 9$ did not differ significantly among feed groups in any tissue. A strong reduction of $m m p 9$ mRNA was identified at 5 dpii in all groups (Supplementary Material 2), but the reason for this was not clear.

\section{Transcriptomic responses of salmon lice to immunostimulated hosts}

To investigate the effect of infecting an immunostimulated Atlantic salmon on a salmon louse, we identified genes differentially expressed between lice infecting immunostimulated (LD) and control (CTL) hosts. Lice infecting LD hosts overexpressed 50 probes (17 unique annotations) and underexpressed 48 probes (14 unique annotations; Table 1). Three genes with carboxylesterase domains (CDD: pfam00135) were overexpressed in lice infecting LD hosts including COesterase (5-fold), esterase sg1 (3.5-fold), and neuroligin-4 (5-fold). Other enzymes overexpressed during infection of LD hosts included histone-lysine N-methyltransferase (SETD7) (7-fold), prolyl 4-hydroxylase subunit alpha-2 ( 4-fold), and heparin sulfate 2-O-sulfotransferase pipe (2.5-fold; Table 1). The transporter nuclear pore membrane glycoprotein 210 was highly overexpressed during infection of LD hosts ( $\sim 9$-fold). Immune-related genes such as granulin-7, saposin-D, and B-cell receptor-associated protein 31 were overexpressed in LD lice compared with controls, although with lower fold change $(\mathrm{FC}=\sim 1.7)$.

Table 1. Differentially expressed genes ( $p \leq 0.05$; linear fold change (FC) $\geq 1.5$ ) overexpressed or underexpressed in salmon lice feeding on low dose (LD) relative to control-fed (CTL) Atlantic salmon.

\begin{tabular}{|c|c|c|c|}
\hline Spot ID & Gene description & $\begin{array}{c}\log _{2}(\mathrm{FC}) \\
\mathrm{LD} / \mathrm{CTL}\end{array}$ & $p$-value \\
\hline C088R114 & Nuclear pore membrane glycoprotein 210 & 3.19 & 0.030 \\
\hline C263R087 & Histone-lysine N-methyltransferase SETD7 & 2.80 & 0.043 \\
\hline C071R157 & Neuroligin-4, Y-linked & 2.44 & 0.025 \\
\hline C170R028 & COesterase, Carboxylesterase & 2.35 & 0.027 \\
\hline C158R069 & Prolyl 4-hydroxylase subunit alpha-2 & 2.20 & 0.019 \\
\hline C042R126 & Esterase SG1 & 1.78 & 0.027 \\
\hline C106R049 & Cytochrome c oxidase subunit 2 & 1.35 & 0.040 \\
\hline C115R122 & Ribosomal_P2, Ribosomal protein P2 & 1.32 & 0.011 \\
\hline C085R082 & Cytochrome b & 1.28 & 0.039 \\
\hline C137R111 & Heparan sulfate 2-O-sulfotransferase pipe & 1.17 & 0.030 \\
\hline C090R084 & Cellular retinoic acid-binding protein 2 & 0.87 & 0.011 \\
\hline C096R097 & Kalirin & 0.77 & 0.016 \\
\hline C225R165 & Granulin-7 & 0.74 & 0.010 \\
\hline C041R134 & B-cell receptor-associated protein 31 & 0.73 & 0.014 \\
\hline C194R080 & Putative glutaminase DH11.1 & 0.72 & $\begin{array}{c}0.027 \\
\text { ntinued) }\end{array}$ \\
\hline
\end{tabular}


Table 1. (concluded)

\begin{tabular}{|c|c|c|c|}
\hline Spot ID & Gene description & $\begin{array}{c}\log _{2}(\mathrm{FC}) \\
\mathrm{LD} / \mathrm{CTL}\end{array}$ & $p$-value \\
\hline C074R109 & Saposin-D & 0.71 & 0.024 \\
\hline C038R133 & Histone deacetylase 6 & 0.66 & 0.031 \\
\hline C074R073 & $\begin{array}{l}\text { Protein farnesyltransferase/geranylgeranyltransferase type-1 } \\
\text { subunit alpha }\end{array}$ & 0.61 & 0.021 \\
\hline C241R004 & Dynamin-like $120 \mathrm{kDa}$ protein, mitochondrial & -0.60 & 0.033 \\
\hline C178R011 & Neuroglian & -0.67 & 0.039 \\
\hline C071R017 & Carbohydrate kinase domain-containing protein & -0.68 & 0.033 \\
\hline C105R103 & NADPH oxidase 5 & -0.70 & 0.020 \\
\hline C087R138 & $\begin{array}{l}\text { Dolichyl-diphosphooligosaccharide-protein } \\
\text { glycosyltransferase subunit } 1\end{array}$ & -0.71 & 0.034 \\
\hline C028R025 & $\begin{array}{l}\text { RT_nLTR_like, RT_nLTR: Non-LTR (long terminal repeat) } \\
\text { retrotransposon and non-LTR retrovirus reverse } \\
\text { transcriptase (RT) }\end{array}$ & -0.72 & 0.005 \\
\hline C137R077 & Muscle M-line assembly protein unc- 89 & -0.92 & 0.029 \\
\hline C025R149 & Dehydrogenase/reductase SDR family member 1 & -1.21 & 0.002 \\
\hline C019R024 & Histone $\mathrm{H} 2 \mathrm{~B}$ & -1.49 & 0.021 \\
\hline C006R098 & Chymotrypsin-like protease CTRL-1 & -1.98 & 0.029 \\
\hline C158R134 & Tryp_SPc, trypsin-like serine protease & -2.00 & 0.050 \\
\hline C021R036 & L-amino-acid oxidase & -2.06 & 0.020 \\
\hline C083R024 & $\begin{array}{l}\text { ZnMc_adamalysin_II_like, zinc-dependent metalloprotease; } \\
\text { adamalysin_II_like subfamily }\end{array}$ & -2.21 & 0.033 \\
\hline C231R055 & Phospholipase A2 & -2.37 & 0.021 \\
\hline C132R072 & Papilin & -2.49 & 0.048 \\
\hline C242R121 & Zinc metalloproteinase nas- 14 & -3.73 & 0.018 \\
\hline C127R029 & Zinc metalloproteinase nas- 6 & -4.36 & 0.014 \\
\hline
\end{tabular}

Note: Fold changes in the table are in $\log _{2}$ scale.

Genes underexpressed in LD-infecting lice included proteases such as zinc metalloproteinase nas-6 and nas-14 ( $\geq 10$-fold), adamlysin_II_like subfamily member ( $\geq 4.5$-fold), trypsin-like serine protease (4-fold), phospholipase A2 (5-fold), papilin (5.5-fold), chymotrypsin-like protease CTRL-1 (4-fold), and dehydrogenase/reductase SDR family member 1 ( $\geq 1.5$-fold), among others (Table 1$)$. Two genes annotated to L-amino-acid oxidase were expressed between 4.2-fold and 4.7-fold lower in LD-feeding lice compared with those on control fish. Many of the differentially expressed lice genes did not have highly significant effects, with only 13 probes showing $p \leq 0.01$, although sample size was low ( $n=4$ for LD infecting $n=7$ for CTL). All differentially expressed genes, including those without annotation (unknown probes), are in Supplementary Material 3.

\section{Validation of louse microarray by RT-qPCR}

The most stable reference candidates were flna and $r p s 20$ with a geNORM $M$-value of 0.38 , indicating sufficient reference gene stability (Hellemans et al. 2007). Three genes selected for validation due to 

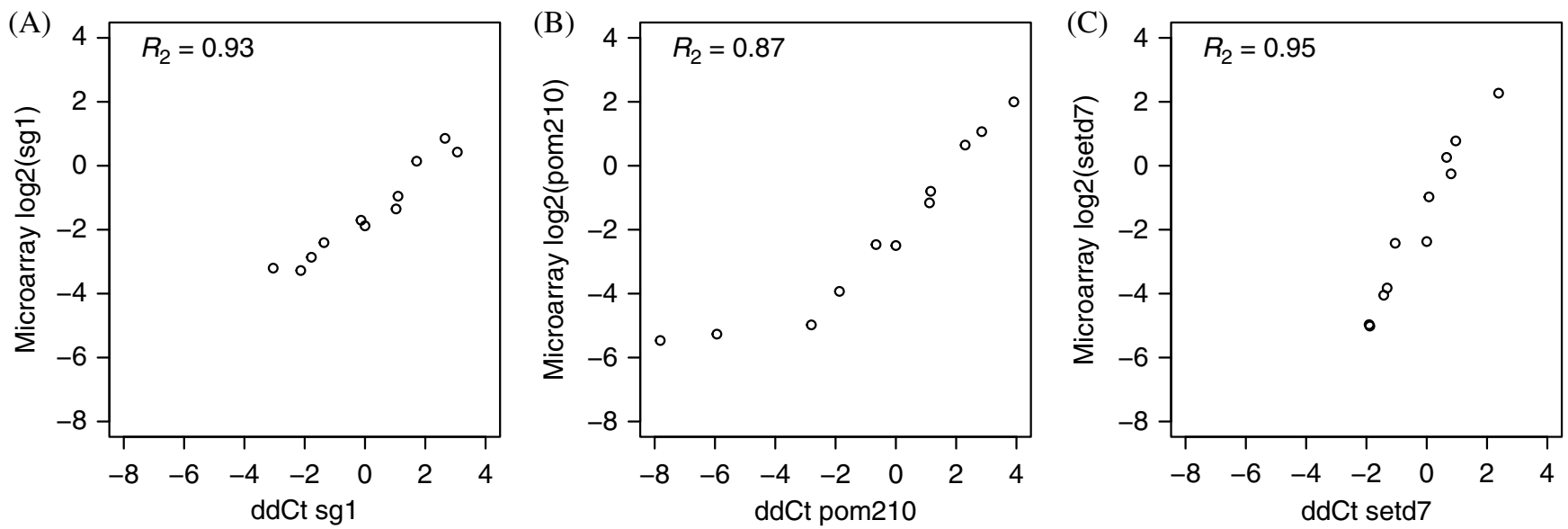

Fig. 4. Microarray and qPCR correlation for lice gene expression. Correlations of lice gene expression values estimated by microarray $\left(\log _{2}\right)$ and by qPCR ( $\mathrm{ddCt}$ ) for (A) sg1, (B) pom210, and (C) setd7.

differential expression in the microarray analysis had a high correlation between the two methods, specifically: esterase sg1, pom210, and setd7 (Fig. 4).

\section{Discussion}

As drug resistance continues to evolve against parasiticides used in salmon aquaculture, it will be important to continue considering complementary methods of parasite control, such as host immunostimulation. The viability of this option requires an effective removal of lice outweighing any negative effects on hosts. This can be intermittently used to boost the host immune response; for example, when no vaccine is available against the pathogen (Casadei et al. 2013). No commercially available vaccine exists for salmon lice L. salmonis, although efforts towards this goal have been made (Raynard et al. 2002).

Targeting the induction of appropriate defenses and immune system components for specific pathogens is important when considering defense (Medzhitov 2007). In rainbow trout, dietary peptidoglycan is being explored as a potential treatment to increase the expression of antimicrobial peptides for elevating immune responses to common bacterial diseases (Casadei et al. 2013). As our knowledge on the appropriate responses to ectoparasites improves (in this case against salmon lice), immunostimulation formulations can be optimized towards the specific parasite (Alvarez-Pellitero 2008).

Pro-inflammatory responses have long been understood to play an important role in salmon lice rejection (Fast 2014). Increased il-1 $\beta$ expression and innate defenses are important for host rejection of salmon lice; this response is not typical of Atlantic salmon, but rather is typical of the more liceresistant pink salmon and coho salmon (Johnson and Albright 1992; Jones et al. 2007; Braden et al. 2012, 2015; Sutherland et al. 2014). However, in previous studies of CpG-ODN immunostimulation, Atlantic salmon fed the treatment diet overexpressed $i l-1 \beta$ and had lower lice infection levels than controls (Covello et al. 2012; Poley et al. 2013). Similarly, here, il-1 $\beta$ was overexpressed in the LD salmon, the group with the lowest infection levels. Although $t$ lr9 was overexpressed in the group fed the immunostimulant diet, the expression of this gene decreased over time. Atlantic salmon CpG-ODN has been shown to bind tlr9 for signaling IFN-related genes (Iliev et al. 2013); it is possible that the current immunostimulant is working through the same pathway, but this would require more work to confirm. Surprisingly, $m m p 9$ was not increased in mRNA levels from the infection, as in 
many other studies, this gene is a reliable indicator of a response to lice infection. The maintenance of a low-level lice infection in this study may not have been sufficient to trigger this response. The biphasic nature of the response of $m m p 9$ has been previously identified (Tadiso et al. 2011) and can change throughout the infection. Although a larger panel of response genes or a full transcriptome profiling would be needed to better understand the host response to the immunostimulant, the expression of il-1 $1 \beta$ coincident with the lower infection levels suggests that the LD immunostimulant enhanced inflammation, directing the Atlantic salmon response towards a more successful lice rejection response.

The overexpression of $i l-1 \beta$ in LD salmon was specific to the skin (the point of $L$. salmonis contact), with minor overexpression ( 1.4 -fold) also observed in the spleen, a secondary hematopoietic organ for salmon. Mucosal immunity is important for ectoparasite defense, and the highest expression changes may be observed in the tissue contacting the ectoparasite (for review, see AlvarezPellitero 2008; Braden et al. 2012). Notably, the transcriptome response of the skin of immunostimulated Atlantic salmon infected with Caligus rogercresseyi provided more information on the host defense response than the expression analysis of the host head kidney (Núñez-Acuña et al. 2015). In the present study, $i l-1 \beta$ levels decreased over time in the anterior kidney (the primary hematopoietic organ of fish; Supplementary Material 2). It is possible that this reflects a shifting tissue distribution of cells expressing this gene, moving from the source to the site of external contact. Further work would be required to confirm this tissue change. Up-regulation of $i l-1 \beta$ in the skin in response to $L$. salmonis has been previously observed. For example, $i l-1 \beta$ expression was up-regulated specifically in the skin of infected pink salmon (considered to be more resistant) but not Atlantic salmon (Sutherland et al. 2014). Considering the potential for immunosuppression of Atlantic salmon by lice-derived $\mathrm{PGE}_{2}$ and other compounds (Fast et al. 2004, 2007), it is interesting that the immunostimulation induced a response more characteristic of a successful rejection, as immunostimulation can negate immune suppression (for review see Vadstein 1997). Up-regulation of $i l-1 \beta$ promotes a T helper 17 response that is important in defense against salmon lice (Skugor et al. 2008), bacteria, and fungi, but is also implicated in auto-immunity (Waite and Skokos 2012), highlighting the importance of dose specificity in levels of effector induction. The response of the LD salmon more reflects the response of pink salmon, suggesting a shift towards a more appropriate defense mechanism.

Although not significant $(p=0.07)$, there was a trend towards the overexpression of $i l-8$ in the LD salmon; an insignificant trend towards overexpression was also previously observed in Atlantic and pink salmon skin (Sutherland et al. 2014). Earlier work found elevated $i l-8$ expression in head kidney/spleen pooled tissues at 7 and $14 \mathrm{~d}$ post infection in juvenile chum (Oncorhynchus keta) and pink salmon but no consistent response in $i l-1 \beta$ (Jones et al. 2008a). Similarly, il-8 was found to be up-regulated at $7 \mathrm{~d}$ post infection in pink salmon anterior kidney and skin (Jones et al. 2007). In the present study, up-regulation of $i l-1 \beta$ occurred consistently in LD-fed Atlantic salmon (the feed group with the lowest infection), as it did in pink salmon skin in previous studies, also coinciding with early responses ( $6 \mathrm{~d}$ after exposure; Sutherland et al. 2014). Between HD and LD, the LD was optimal here in terms of $i l-1 \beta$ induction and reduction in lice infection levels.

Genes underexpressed in lice parasitizing LD salmon included protein degradation genes potentially involved in feeding on susceptible hosts such as Atlantic salmon (e.g., metalloproteinases, chymotrypsin, and trypsin-like serine protease; Braden et al. 2017). Lower activity and presence of similar enzymes was previously observed when lice were exposed to mucus from less optimal hosts (e.g., coho salmon), unsuitable hosts (e.g., winter flounder, Pseudopleuronectes americanus), or seawater (Fast et al. 2003). Three additional genes underexpressed in LD-feeding lice included the protease inhibitor 
papilin and two genes annotated to L-amino-acid oxidase, an enzyme found in snake venom (Du and Clemetson 2002). The papilin sequence contains a protease inhibitor domain (kunitz; CDD: pfam00014) frequently observed in tick salivary secretions (Francischetti et al. 2009; Tirloni et al. 2014), though the oxidases could have roles in virulence based on their annotations to the Malayan pit viper (Calloselasma rhodostoma) and Australian taipan (Oxyuranus scutellatus). More work is needed to understand exactly the relation of specific transcripts to the feeding response of L. salmonis; however, this suggests that the feeding response of lice infecting LD salmon may be reduced.

An analysis of immunostimulation on the Caligid sea lice (Caligus rogercresseyi) identified four ionotropic receptors as differentially expressed in Atlantic salmon exposed to $1 \%$ peptidoglycan in-feed (Núñez-Acuña et al. 2016). A tblastx search $\left(\mathrm{e}<10^{-10}\right)$ of the L. salmonis transcriptome using these C. rogercresseyi sequences as a query resulted in the identification of their putative orthologues. The four C. rogercresseyi genes ionotropic kainite 2 receptor (KAR-2; GenBank: KJ002538.1), KAR-2-like-a (KJ002539.1), KAR-2-like-b (KJ002540.1), and ionotropic glutamate 25a receptor (KJ002537.1) matched L. salmonis probes C045R029, C139R121, C082R071, and C217R137, respectively. Although these probes passed quality filters (Supplementary Material 3), they were not differentially expressed here.

Genes overexpressed in lice parasitizing LD salmon were those related to lice survival on immunostimulated hosts and may provide insight into mechanisms of host immune evasion. Interestingly, carboxylesterases were abundant in this list of response genes. It will be important to continue exploring genes that may provide protection against the innate immunity of various salmonids. Interestingly, immune-related genes in the lice were also slightly overexpressed when feeding on immunostimulated fish, including granulin-7, saposin-D, and B-cell receptor-associated protein 31 . It remains unclear if the parasite consumes any of the immunostimulant through feeding on host mucous, skin, or blood during infection, and if this consumption can impact its physiology. As carboxylesterases also have roles in immunity in arthropods (Johansson et al. 2005; Albert et al. 2011), it will be important to determine if lice can be immunostimulated through feeding on treated hosts, and how this might impact louse responses to other treatments. However, determining whether the louse response is due to an enhanced host response or directly to the immunostimulant is not possible here.

Some similarities in identities of differentially expressed lice genes were present between lice-infecting LD salmon and lice with elevated resistance to EMB (trade name: SLICE). For example, putative collagenases were underexpressed in LD-feeding lice but overexpressed in EMB-resistant lice (Sutherland et al. 2015), such as trypsin-like serine protease, and nas-6 and -14. Also, collagenases were overexpressed in EMB-resistant males (i.e., the most resistant group of L. salmonis in Sutherland et al. 2015), and here, lice-infecting LD salmon overexpressed setd7, a histone methyltransferase chromatin remodeler involved in induction of collagenase transcription (Martens et al. 2003). Interestingly, a link between immunostimulation and EMB response has been previously identified in L. salmonis (Atlantic subspecies); lice feeding on CpG-ODN immunostimulated hosts showed higher EMB tolerance than those on normal hosts (Poley et al. 2013). The authors propose that genes such as monooxygenases could be induced by feeding on an immunostimulated host, and that this increased expression of monooxygenases could prime lice against EMB or buffer against consequences of EMB exposure. In another study, lice feeding on immunostimulated hosts had elevated p-glycoprotein expression, a potential resistance mechanism against EMB (Igboeli et al. 2012), and had higher survival after infecting EMB-fed salmon (Igboeli et al. 2013). It will be important to determine effective combinations of control strategies, as they may not all be compatible. More work would be required to understand the molecular signaling involved in these responses and the potential antagonistic or synergistic effects of prior host immunostimulation and subsequent chemical interventions. 


\section{Conclusions}

The diet formulations (specifically the LD immunostimulant diet) decreased infection intensity of L. salmonis on Atlantic salmon in this study. Incorporation of this type of treatment into a control strategy may provide complementarity to existing therapies, although further work will be needed to test the efficacy of combinatorial treatments. Induced responses in Atlantic salmon coincided with $i l-1 \beta$ expression, which is not common to standard Atlantic salmon responses but is rather more similar to successful lice rejections by more resistant Pacific salmon species such as adult coho and pink salmon. Lice infecting the immunostimulated hosts were also affected by the different host treatments, increasing expression of genes putatively protective against increased host defense, and decreasing genes that associated with feeding responses. Whether these changes are induced directly by residual immunostimulant in the host or to the host response itself remains unknown but an important avenue of future investigation.

\section{Acknowledgements}

The authors would like to thank EWOS Innovation, Novartis Animal Health Canada (Dr. Fast's Research Chair in fish health), NSERC Engage and Discovery programs, and Innovation PEI (student and PDF scholarships) for funding this research; Department of Pathology and Microbiology and Merial scholarships at AVC-UPEI for summer research interns; and the Aquatics Facilities and Staff at the Atlantic Veterinary College for their role in maintaining the Atlantic salmon. BJGS was supported during this work by NSERC-CGS and PDF fellowships.

\section{Author contributions}

Conceived and designed the study: BJGS, BFK, SLW, MDF. Performed the experiments/collected the data: BJGS, JMC, SEF, KWK, SLP, TLM, BRD, JP, JLG-V, JG, JT. Analyzed and interpreted the data: BJGS, JDP, BFK, MDF. Contributed resources: BFK, SLW, MDF. Drafted or revised the manuscript: BJGS, JDP, BFK, MDF.

\section{Competing interests}

Members of the author list and their affiliates utilize similar feed additives to produce commercial functional feeds to control pathogen infection in salmon.

\section{Data accessibility statement}

All relevant data are within the paper, the Supplementary Material, and the Gene Expression Omnibus repository. The raw and normalized transcriptome data have been uploaded to Gene Expression Omnibus under accession GSE93998. All code for the analysis can be obtained along with a readme for performing the analysis at: github.com/bensutherland/2017_ms_immunostim/.

\section{Supplementary material}

The following Supplementary Material is available with the article through the journal website at doi:10.1139/facets-2017-0020.

Supplementary Material 1: Primer sequences, annealing temperatures, efficiencies, and amplicon sizes for genes of interest and reference genes used for RT-qPCR in Atlantic salmon (Salmo salar) and salmon louse (Lepeophtheirus salmonis).

Supplementary Material 2: Gene expression profiles of four immune-related genes (il-1b, il-8, tlr9, and $m m p 9$ ) in salmon skin, anterior kidney, and spleen. 
Supplementary Material 3: All differentially expressed genes in the salmon lice infecting immunostimulant-fed Atlantic salmon, including probes without annotation (unknowns). The background list of all probes passing quality control filters is included.

\section{References}

Aaen SM, Helgesen KO, Bakke MJ, Kaur K, and Horsberg TE. 2015. Drug resistance in sea lice: a threat to salmonid aquaculture. Trends in Parasitology, 31: 72-81. PMID:25639521. doi:10.1016/j. pt.2014.12.006.

Albert Š, Gätschenberger H, Azzami K, Gimple O, Grimmer G, Sumner S, et al. 2011. Evidence of a novel immune responsive protein in the Hymenoptera. Insect Biochemistry and Molecular Biology, 41: 968-981. PMID:22001069. doi:10.1016/j.ibmb.2011.09.006.

Alvarez-Pellitero P. 2008. Fish immunity and parasite infections: from innate immunity to immunoprophylactic prospects. Veterinary Immunology and Immunopathology, 126: 171-198. PMID:18783835. doi:10.1016/j.vetimm.2008.07.013.

Braden LM, Barker DE, Koop BF, and Jones SRM. 2012. Comparative defense-associated responses in salmon skin elicited by the ectoparasite Lepeophtheirus salmonis. Comparative Biochemistry and Physiology Part D: Genomics and Proteomics, 7: 100-109. PMID:22244883. doi:10.1016/j. cbd.2011.12.002.

Braden LM, Koop BF, and Jones SRM. 2015. Signatures of resistance to Lepeophtheirus salmonis include a $\mathrm{T}_{\mathrm{H}} 2$-type response at the louse-salmon interface. Developmental \& Comparative Immunology, 48: 178-191. PMID:25453579. doi:10.1016/j.dci.2014.09.015.

Braden LM, Sutherland BJG, Koop BF, and Jones SRM. 2017. Enhanced transcriptomic responses in the Pacific salmon louse Lepeophtheirus salmonis oncorhynchi to the non-native Atlantic salmon Salmo salar suggests increased parasite fitness. BMC Genomics, 18: 110. PMID:28137252. doi:10.1186/s12864-017-3520-1.

Bricknell I, and Dalmo RA. 2005. The use of immunostimulants in fish larval aquaculture. Fish \& Shellfish Immunology, 19: 457-472. PMID:15890531. doi:10.1016/j.fsi.2005.03.008.

Burka JF, Hammell KL, Horsberg TE, Johnson GR, Rainnie DJ, and Speare DJ. 1997. Drugs in salmonid aquaculture-a review. Journal of Veterinary Pharmacology and Therapeutics, 20: 333-349. PMID:9350253. doi:10.1046/j.1365-2885.1997.00094.x.

Burridge L, Weis JS, Cabello F, Pizarro J, and Bostick K. 2010. Chemical use in salmon aquaculture: a review of current practices and possible environmental effects. Aquaculture, 306: 7-23. doi:10.1016/j. aquaculture.2010.05.020.

Canadian Council on Animal Care. 2005. CCAC Guidelines on: the care and use of fish in research, teaching and testing. CCAC, Ottawa, Ontario [online]: Available from ccac.ca/Documents/ Standards/Guidelines/Fish.pdf.

Casadei E, Bird S, Vecino JLG, Wadsworth S, and Secombes CJ. 2013. The effect of peptidoglycan enriched diets on antimicrobial peptide gene expression in rainbow trout (Oncorhynchus mykiss). Fish \& Shellfish Immunology, 34: 529-537. PMID:23220715. doi:10.1016/j.fsi.2012.11.027.

Costello MJ. 2009. The global economic cost of sea lice to the salmonid farming industry. Journal of Fish Diseases, 32: 115-118. PMID:19245636. doi:10.1111/j.1365-2761.2008.01011.x. 
Covello JM, Friend SE, Purcell SL, Burka JF, Markham RJF, Donkin AW, et al. 2012. Effects of orally administered immunostimulants on inflammatory gene expression and sea lice (Lepeophtheirus salmonis) burdens on Atlantic salmon (Salmo salar). Aquaculture, 366-367: 9-16. doi:10.1016/j. aquaculture.2012.08.051.

Du X-Y, and Clemetson KJ. 2002. Snake venom L-amino acid oxidases. Toxicon, 40: 659-665. PMID:12175601. doi:10.1016/S0041-0101(02)00102-2.

Fast MD. 2014. Fish immune responses to parasitic copepod (namely sea lice) infection. Developmental \& Comparative Immunology, 43: 300-312. PMID:24001580. doi:10.1016/j. dci.2013.08.019.

Fast MD, Burka JF, Johnson SC, and Ross NW. 2003. Enzymes released from Lepeophtheirus salmonis in response to mucus from different salmonids. Journal of Parasitology, 89: 7-13. PMID:12659296. doi:10.1645/0022-3395(2003)089[0007:ERFLSI]2.0.CO;2.

Fast MD, Ross NW, Craft CA, Locke SJ, MacKinnon SL, and Johnson SC. 2004. Lepeophtheirus salmonis: characterization of prostaglandin $\mathrm{E}_{2}$ in secretory products of the salmon louse by RP-HPLC and mass spectrometry. Experimental Parasitology, 107: 5-13. PMID:15208032. doi:10.1016/j.exppara.2004.04.001.

Fast MD, Johnson SC, Eddy TD, Pinto D, and Ross NW. 2007. Lepeophtheirus salmonis secretory/ excretory products and their effects on Atlantic salmon immune gene regulation. Parasite Immunology, 29: 179-189. PMID:17371455. doi:10.1111/j.1365-3024.2007.00932.x.

Francischetti IMB, Sa-Nunes A, Mans BJ, Santos IM, and Ribeiro JMC. 2009. The role of saliva in tick feeding. Frontiers in Bioscience, 14: 2051-2088. PMID:19273185. doi:10.2741/3363.

Frost P, and Nilsen F. 2003. Validation of reference genes for transcription profiling in the salmon louse, Lepeophtheirus salmonis, by quantitative real-time PCR. Veterinary Parasitology, 118: 169-174. PMID:14651887. doi:10.1016/j.vetpar.2003.09.020.

Gharbi K, Matthews L, Bron J, Roberts R, Tinch A, and Stear M. 2015. The control of sea lice in Atlantic salmon by selective breeding. Journal of the Royal Society Interface, 12: 20150574. PMID:26289656. doi:10.1098/rsif.2015.0574.

Gjerde B, Ødegård J, and Thorland I. 2011. Estimates of genetic variation in the susceptibility of Atlantic salmon (Salmo salar) to the salmon louse Lepeophtheirus salmonis. Aquaculture, 314: 66-72. doi:10.1016/j.aquaculture.2011.01.026.

Hamre LA, Eichner C, Caipang CMA, Dalvin ST, Bron JE, Nilsen F, et al. 2013. The salmon louse Lepeophtheirus salmonis (Copepoda: Caligidae) life cycle has only two chalimus stages. PLoS ONE, 8: e73539. PMID:24069203. doi:10.1371/journal.pone.0073539.

Hellemans J, Mortier G, De Paepe A, Speleman F, and Vandesompele J. 2007. qBase relative quantification framework and software for management and automated analysis of real-time quantitative PCR data. Genome Biology, 8: R19. PMID:17291332. doi:10.1186/gb-2007-8-2-r19.

Igboeli OO, Fast MD, Heumann J, and Burka JF. 2012. Role of P-glycoprotein in emamectin benzoate $\left(\right.$ SLICE $\left.^{\circledR}\right)$ resistance in sea lice, Lepeophtheirus salmonis. Aquaculture, 344-349: 40-47. doi:10.1016/j. aquaculture.2012.03.026. 
Igboeli OO, Purcell SL, Wotton H, Poley J, Burka JF, and Fast MD. 2013. Immunostimulation of Salmo salar L., and its effect on Lepeophtheirus salmonis (Krøyer) P-glycoprotein mRNA expression following subsequent emamectin benzoate exposure. Journal of Fish Diseases, 36: 339-351. PMID:23305391. doi:10.1111/jfd.12063.

Igboeli OO, Burka JF, and Fast MD. 2014. Sea lice population and sex differences in P-glycoprotein expression and emamectin benzoate resistance on salmon farms in the Bay of Fundy, New Brunswick, Canada. Pest Management Science, 70: 905-914. PMID:23913539. doi:10.1002/ps.3620.

Iliev DB, Skjæveland I, and Jørgensen JB. 2013. CpG oligonucleotides bind TLR9 and RRMcontaining proteins in Atlantic salmon (Salmo salar). BMC Immunology, 14: 12. PMID:23452377. doi:10.1186/1471-2172-14-12.

Jensen LB, Provan F, Larssen E, Bron JE, and Obach A. 2015. Reducing sea lice (Lepeophtheirus salmonis) infestation of farmed Atlantic salmon (Salmo salar L.) through functional feeds. Aquaculture Nutrition, 21: 983-993. doi:10.1111/anu.12222.

Johansson KC, Metzendorf C, and Söderhäll K. 2005. Microarray analysis of immune challenged Drosophila hemocytes. Experimental Cell Research, 305: 145-155. PMID:15777795. doi:10.1016/j. yexcr.2004.12.018.

Johnson SC, and Albright LJ. 1992. Comparative susceptibility and histopathology of the response of naive Atlantic, chinook and coho salmon to experimental infection with Lepeophtheirus salmonis (Copepoda: Caligidae). Diseases of Aquatic Organisms, 14: 179-193. doi:10.3354/dao014179.

Jones SRM, Fast MD, Johnson SC, and Groman DB. 2007. Differential rejection of salmon lice by pink and chum salmon: disease consequences and expression of proinflammatory genes. Diseases of Aquatic Organisms, 75: 229-238. PMID:17629118. doi:10.3354/dao075229.

Jones SRM, Fast MD, and Johnson SC. 2008a. Influence of reduced feed ration on Lepeophtheirus salmonis infestation and inflammatory gene expression in juvenile pink salmon. Journal of Aquatic Animal Health, 20: 103-109. PMID:18783131. doi:10.1577/H07-014.1.

Jones SRM, Kim E, and Bennett W. 2008b. Early development of resistance to the salmon louse, Lepeophtheirus salmonis (Krøyer), in juvenile pink salmon, Oncorhynchus gorbuscha (Walbaum). Journal of Fish Diseases, 31: 591-600. PMID:18482380. doi:10.1111/j.1365-2761.2008.00933.x.

Kolstad K, Heuch PA, Gjerde B, Gjedrem T, and Salte R. 2005. Genetic variation in resistance of Atlantic salmon (Salmo salar) to the salmon louse Lepeophtheirus salmonis. Aquaculture, 247: 145-151. doi:10.1016/j.aquaculture.2005.02.009.

Martens JHA, Verlaan M, Kalkhoven E, and Zantema A. 2003. Cascade of distinct histone modifications during collagenase gene activation. Molecular and Cellular Biology, 23: 1808-1816. PMID:12588998. doi:10.1128/MCB.23.5.1808-1816.2003.

McNair CM. 2015. Ectoparasites of medical and veterinary importance: drug resistance and the need for alternative control methods. Journal of Pharmacy and Pharmacology, 67: 351-363. PMID:25644683. doi:10.1111/jphp.12368.

Medzhitov R. 2007. Recognition of microorganisms and activation of the immune response. Nature, 449: 819-826. PMID:17943118. doi:10.1038/nature06246. 
Núñez-Acuña G, Gonçalves AT, Valenzuela-Muñoz V, Pino-Marambio J, Wadsworth S, and Gallardo-Escárate C. 2015. Transcriptome immunomodulation of in-feed additives in Atlantic salmon Salmo salar infested with sea lice Caligus rogercresseyi. Fish \& Shellfish Immunology, 47: 450-460. PMID:26363235. doi:10.1016/j.fsi.2015.09.009.

Núñez-Acuña G, Vera-Bizama F, Boltaña S, Hawes C, Marambio JP, Wadsworth S, et al. 2016. In-feed additives modulate ionotropic receptor genes from the sea louse Caligus rogercresseyi: a comparative analysis in two host salmonid species. Aquaculture, 451: 99-105. doi:10.1016/j.aquaculture. 2015.09.001.

Perkins JR, Dawes JM, McMahon SB, Bennett DLH, Orengo C, and Kohl M. 2012. ReadqPCR and NormqPCR: R packages for the reading, quality checking and normalisation of RT-qPCR quantification cycle (Cq) data. BMC Genomics, 13: 296. PMID:22748112. doi:10.1186/1471-2164-13-296.

Pike AW, and Wadsworth SL. 1999. Sealice on salmonids: their biology and control. Advances in Parasitology, 44: 233-337. PMID:10563397. doi:10.1016/S0065-308X(08)60233-X.

Poley J, Purcell SL, Igboeli OO, Donkin A, Wotton H, and Fast MD. 2013. Combinatorial effects of administration of immunostimulatory compounds in feed and follow-up administration of tripledose SLICE ${ }^{\circledR}$ (emamectin benzoate) on Atlantic salmon, Salmo salar L., infection with Lepeophtheirus salmonis. Journal of Fish Diseases, 36: 299-309. PMID:23311884. doi:10.1111/ jfd.12062.

Purcell SL, Friend SE, Covello JM, Donkin A, Groman DB, Poley J, et al. 2013. CpG inclusion in feed reduces sea lice, Lepeophtheirus salmonis, numbers following re-infection. Journal of Fish Diseases, 36: 229-240. PMID:23163585. doi:10.1111/jfd.12024.

R Core Team. 2017. R: a language and environment for statistical computing. R Foundation for Statistical Computing, Vienna, Austria [online]: Available from R-project.org/.

Raynard RS, Bricknell IR, Billingsley PF, Nisbet AJ, Vigneau A, and Sommerville C. 2002. Development of vaccines against sea lice. Pest Management Science, 58: 569-575. PMID:12138623. doi:10.1002/ps.474.

Ritchie ME, Silver J, Oshlack A, Holmes M, Diyagama D, Holloway A, et al. 2007. A comparison of background correction methods for two-colour microarrays. Bioinformatics, 23: 2700-2707. PMID:17720982. doi:10.1093/bioinformatics/btm412.

Skugor S, Glover KA, Nilsen F, and Krasonov A. 2008. Local and systemic gene expression responses of Atlantic salmon (Salmo salar L.) to infection with the salmon louse (Lepeophtheirus salmonis). BMC Genomics, 9: 498. PMID:18945374. doi:10.1186/1471-2164-9-498.

Smyth GK. 2004. Linear models and empirical Bayes methods for assessing differential expression in microarray experiments. Statistical Applications in Genetics and Molecular Biology, 3: 1-25. PMID:16646809. doi:10.2202/1544-6115.1027.

Smyth GK, and Speed T. 2003. Normalization of cDNA microarray data. Methods, 31: 265-273. PMID:14597310. doi:10.1016/S1046-2023(03)00155-5.

Sutherland BJG, Jantzen SG, Sanderson DS, Koop BF, and Jones SRM. 2011. Differentiating sizedependent responses of juvenile pink salmon (Oncorhynchus gorbuscha) to sea lice (Lepeophtheirus salmonis) infections. Comparative Biochemistry and Physiology Part D: Genomics and Proteomics, 6: 213-223. PMID:21543273. doi:10.1016/j.cbd.2011.04.001. 
Sutherland BJG, Jantzen SG, Yasuike M, Sanderson DS, Koop BF, and Jones SRM. 2012. Transcriptomics of coping strategies in free-swimming Lepeophtheirus salmonis (Copepoda) larvae responding to abiotic stress. Molecular Ecology, 21: 6000-6014. PMID:23094868. doi:10.1111/ mec.12072.

Sutherland BJG, Koczka KW, Yasuike M, Jantzen SG, Yazawa R, Koop BF, et al. 2014. Comparative transcriptomics of Atlantic Salmo salar, chum Oncorhynchus keta and pink salmon O. gorbuscha during infections with salmon lice Lepeophtheirus salmonis. BMC Genomics, 15: 200. PMID:24628956. doi:10.1186/1471-2164-15-200.

Sutherland BJG, Poley JD, Igboeli OO, Jantzen JR, Fast MD, Koop BF, et al. 2015. Transcriptomic responses to emamectin benzoate in Pacific and Atlantic Canada salmon lice Lepeophtheirus salmonis with differing levels of drug resistance. Evolutionary Applications, 8: 133-148. PMID:25685190. doi:10.1111/eva.12237.

Tadiso TM, Krasnov A, Skugor S, Afanasyev S, Hordvik I, and Nilsen F. 2011. Gene expression analyses of immune responses in Atlantic salmon during early stages of infection by salmon louse (Lepeophtheirus salmonis) revealed bi-phasic responses coinciding with the copepod-chalimus transition. BMC Genomics, 12: 141. PMID:21385383. doi:10.1186/1471-2164-12-141.

Tirloni L, Reck J, Terra RMS, Martins JR, Mulenga A, Sherman NE, et al. 2014. Proteomic analysis of cattle tick Rhipicephalus (Boophilus) microplus saliva: a comparison between partially and fully engorged females. PLoS ONE, 9: e94831. PMID:24762651. doi:10.1371/journal.pone.0094831.

Torrissen O, Jones SRM, Asche F, Guttormsen A, Skilbrei OT, Nilsen F, et al. 2013. Salmon liceimpact on wild salmonids and salmon aquaculture. Journal of Fish Diseases, 36: 171-194. PMID:23311858. doi:10.1111/jfd.12061.

Vadstein O. 1997. The use of immunostimulation in marine larviculture: possibilities and challenges. Aquaculture, 155: 401-417. doi:10.1016/S0044-8486(97)00114-2.

Vandesompele J, De Preter K, Pattyn F, Poppe B, Van Roy N, De Paepe A, et al. 2002. Accurate normalization of real-time quantitative RT-PCR data by geometric averaging of multiple internal control genes. Genome Biology, 3: RESEARCH0034. PMID:12184808. doi:10.1186/gb-2002-3-7-research0034.

Veldhoen N, Ikonomou MG, Buday C, Jordan J, Rehaume V, Cabecinha M, et al. 2012. Biological effects of the anti-parasitic chemotherapeutant emamectin benzoate on a non-target crustacean, the spot prawn (Pandalus platyceros Brandt, 1851) under laboratory conditions. Aquatic Toxicology, 108: 94-105. PMID:22088864. doi:10.1016/j.aquatox.2011.10.015.

Wagner GN, Fast MD, and Johnson SC. 2008. Physiology and immunology of Lepeophtheirus salmonis infections of salmonids. Trends in Parasitology, 24: 176-183. PMID:18329341. doi:10.1016/j.pt.2007.12.010.

Waite JC, and Skokos D. 2012. Th17 response and inflammatory autoimmune diseases. International Journal of Inflammation, 2012: 819467. PMID:22229105. doi:10.1155/2012/819467.

Yáñez JM, Houston RD, and Newman S. 2014. Genetics and genomics of disease resistance in salmonid species. Frontiers in Genetics, 5: 415. PMID:25505486. doi:10.3389/fgene.2014.00415.

Yasuike M, Leong J, Jantzen SG, von Schalburg KR, Nilsen F, Jones SRM, et al. 2012. Genomic resources for sea lice: analysis of ESTs and mitochondrial genomes. Marine Biotechnology, 14: 155-166. PMID:21748342. doi:10.1007/s10126-011-9398-z. 